\title{
THE EFFECTS OF AIRBNB ON HOTELS IN NORWAY
}

\author{
ABBAS STRØMMEN-BAKHTIAR ${ }^{1}$ - EVGUENI VINOGRADOV² \\ Graduate School of Business, Nord University, Bodø, Norway \\ Email: abbas.strommen-bakhtiar@nord.no \\ Nordland Research Institute, Bodø, Norway \\ Email:evi@nforsk.no
}

This paper examines the effects of Airbnb on the Norwegian hotel market, using correlational design and the difference-in-differences statistical method. The findings show that hotels in the regions of Norway where Airbnb is flourishing have more guests than the regions with less Airbnb activity. In addition, it seems that Airbnb has a positive effect on the hotel market in Norway. However, as the Airbnb expansion continues, and it diversifies into the 'travel business' and the 'luxury accommodation' segment, it will affect the hotel industry. How the hotel industry will respond to this threat remains to be seen, and will provide an interesting subject for future research.

Keywords: peer-to-peer, Airbnb, hotel industry, leisure travel, business travel, travel agencies

JEL-codes: L83, L85, O18

\section{INTRODUCTION}

For many countries, tourism is a major source of employment and national income. According to the World Travel and Tourism Council (WTTC), tourism has contributed \$7.6 trillion to the world's GDP and currently employs 292 million people or provides one out of ten jobs worldwide. In addition, globally, tourism with the growth of $3.3 \%$, is the second fastest growing industry after the $4.2 \%$ growth of the information and communication industry (WTTC 2017). It is therefore extremely important to understand the underlying factors that affect this industry.

The tourism industry has always been affected by technology and process innovations, but seldom by innovations that have been originated from within it- 
self. As a matter of fact, various studies have shown that the tourism industry, for example hotels and restaurants, are not very innovative (Camisón - Monfort-Mir 2012; Miles 2008). Furthermore, innovations that have been affecting the tourism industry have mostly been invented to improve existing technologies/processes or to solve problems unrelated to tourism. Hjalager (2015) lists 100 such innovations, from passports (year 1414), and highways (year 1922) to body scanning (year 2007) that were not specifically invented for tourism, yet have profoundly affected the tourism industry.

The recent advances and innovations in information technology, especially the Internet and Web 2.0, along with the Global Positioning System (GPS) (Korpilo et al. 2017; Zheng et al. 2017) and mobile phones (Brown and Chalmers 2003; Dickinson et al. 2017; Gunawan - Purnama 2015) are once again affecting the tourism industry in profound ways. These technologies have facilitated the creation of a new business model, called platform. According to Paul S. Chaudary (2015: 301), these platforms play two specific roles: 'they provide an open, participative, plug-and-play infrastructure for producers and consumers to plug into and interact with each other; and they curate participants on the platform and govern the social and economic interactions that ensue...'. Amazon, Apple, Facebook, Google, Airbnb, Lyft and Uber are some of the platforms that are fundamentally changing the way many industries operate.

One of these business models, 'the short-term letting platform', has received considerable attention from the public as well as the municipal and tax authorities. Companies such as Airbnb initially aimed at the lower end of the leisure market, i.e., covering single rooms, or entire units. However, as this platform has become increasingly popular with the public, it is expanding beyond low-end accommodations for the cheap leisure market. Therefore, as Airbnb continues to expand, it is slowly encroaching into other areas and some see this as a growing threat to commercial hotels, motels, and bed and breakfast establishments. For example, a recent report by HVS Global Hospitality Services concluded that hotels lose approximately $\$ 450$ million in direct revenues per year to Airbnb (Mahmood 2016). Another major study also pointed at Airbnb's effect on hotel prices, concluding that by 2020 Airbnb's market share will be high enough to affect hotel prices, especially those of lower end hotels and motels (Consigli et al. 2012).

The results of these studies are not of course applicable to all countries since differences in local rules and regulations, attractiveness of locations, customs, etc., influence the expansion of the Airbnb. This why it is necessary to examine the effect of Airbnb on hotels in each country, in this case Norway. 


\section{LITERATURE REVIEW}

One of the inherent characteristics of capitalism as stated by Schumpeter (1942) is the concept of 'creative destruction'. New technologies, processes, or organizational developments result in various 'mutations' that at times result in fundamental restructuring of the economic structure from within, giving birth to new structures, while destroying the old. He argued that this creative destruction is the essential fact about capitalism.

A new wave of creative destruction is currently underway, made possible by advancements in information and communication technologies (ITC), GPS, and new payment solutions. Of special interest is the rise of new business models, based on what is called the platform. At its most basic form, a platform creates value by facilitating exchanges between consumers and producers.

Access economy, peer economy, on demand economy, collaborative economy, gig economy, people economy, enabling economy, empowering economy and sharing economy are some of the synonyms used for these platform-based business models. These business models increase market efficiency by reducing the search and payment transaction costs. This reduction in costs has enabled the providers, for example of rental units or various consumer goods, to reduce the lending time from months to weeks or in some cases even hours. For example, it used to take days to search and find customers or suppliers, conduct negotiations, and check reliability (establishing trust). All these activities are now performed on these platforms within a few minutes and at a fraction of the cost.

These platforms are disrupting / transforming many industries. The disruption of industries' cost structures along with evading established regulations have created much debate about the effects and legality of these new businesses. There are those that see these platform business models (PBMs) as the solution to prevailing consumerism (Agyeman et al. 2013; Brown - Vergragt 2015; Heinrichs 2013), while others such as Martin et al. (2015), Mohler (2015) or Morozov (2013) see it as the continuation of neoliberal capitalism. Similarly, Slee (2016: 102) sees these business models as a movement for deregulation. There are still others that focus mainly on the legal and financial perspective (Kassan - Orsi 2012; Zervas et al. 2015). However, regardless of the perspective one adopts, the fact remains that the 'sharing economy' or platform-based companies are disrupting the traditional industries. None has apparently received more name recognition than the sharing economy's poster child, the Airbnb.

Airbnb was started by two friends, Brian Chesky and Joe Gebbia in 2007. Facing difficulty in making the monthly rent payment on their San Francisco small apartment, they decided to turn their living room into a bed and breakfast, accommodating three guests on airbeds and providing homemade breakfast. In 


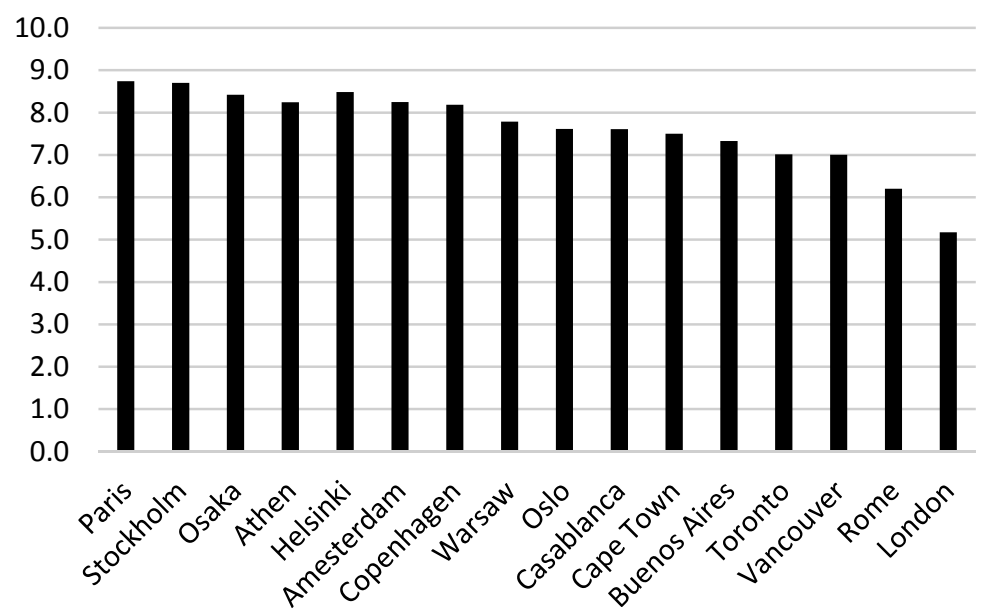

Figure 1. Share of entire units among Airbnb listings, 2016, percentage

Source: Airbnb.com (2016).

2010, they received venture capital funding and so began the meteoric rise of this small company. Today, Airbnb is present in 191 countries and covers 34,000 cities worldwide, with highest growth being in the traditional tourist destinations such as Paris, London, New York, Rome, and the like. Most of the listings in these locations is for the entire place, rather than a room in an apartment or a house (Figure 1).

Airbnb currently boast 3,000,000 listings across the globe, making it by far the largest provider of short-term rental accommodations in the world, surpassing Marriot International, the largest hotel chain in the world (Table 1).

Table 1. The Largest Hotel Companies as of 2016, plus Airbnb

\begin{tabular}{l|l|c|c}
\hline Ranking & Hotel & Properties & Nr. of Rooms \\
\hline 1 & Marriot International & 5,929 & $1,158,107$ \\
\hline 2 & Hilton Inc. & 4,856 & 790,659 \\
\hline 3 & InterContinental Hotels Group & 5,034 & 727,820 \\
\hline 4 & Wyndham & 7,699 & 675,036 \\
\hline 5 & AccorHotels Group & 3,897 & 528,369 \\
\hline & Airbnb & & $3,000,000$ \\
\hline
\end{tabular}

Source: BusNow.com and Airbnb.com (2016) 


\subsection{Success Factors in the Hotel Industry}

Prior to the advent of Airbnb, hotels competed on several factors, with some of the most prominent being customer loyalty, image, and price. Kandampully and Suhartanto's (2000) study of New Zealand hotels concluded that there is a positive correlation between housekeeping, reception, food and beverage and price with customer satisfaction and the hotel's image. Chu and Choi's (2000) study of the Hong Kong hotel industry pointed to the room, front desk, and security as being more valued by Hong Kong customers than food and recreation. Parasuraman et al. (1988) mention the quality of personal interaction with employees as a critical component. And finally, the price of course has always been an important factor, especially for the midrange hotels and low budget motels/hotels (Lewis 1985). With regard to the business travelers, Lewis and Chambers (1989) and McCleary et al. (1993) found that location was the most important influencing factor in their hotel selection. As shown in this paper, Airbnb has been successful in addressing most of these issues.

\subsection{Airbnb's Popularity}

Clearly, Airbnb and other short-term letting platforms have proved extremely popular with the public. This popularity can be attributed to the effects of what Vargo and Lush (2004) call the service-dominant logic (SDL), where instead of traditional focus on production and sales of goods separate from the consumer, the focus is on concepts such as intangibles, competences, dynamics, exchange processes and relationships. In SDL, the customer is seen as 'an operant resource (co-producer) rather than operand resource ("target") and can be involved in the entire value and service chain in acting on operand resources' (Vargo and Lush 2004: 11). Coproduction is one of the main points of SDL. Indeed, Shaw et al. (2011: 13) argue that 'S-D Logic emphasizes that the role of consumers in the co-production process is critical to understanding competitiveness.' Mathis et al. (2016) also mention the importance of co-creation. Their findings 'indicate that satisfaction with co-creation of an experience (i.e., tourists collaborating with a travel professional to provide their own ideas, and express their needs and desires to ensure that the trip is tailored to them personally) can contribute to satisfaction with the vacation' (2016: 72).

The short-term letting platforms such as Airbnb, provide an excellent tool for customization of the accommodation (location, type, services, etc.), as well as providing the users with the means of not only evaluating their service providers, but also to engage in story-telling; something that can result in the enhancement 
of the consumer's experience. Pera (2017: 337) argues that 'the data show that online reviews published by travelers regarding a tourism experience tell stories to enact an account of themselves, and compelling storytelling results in traveler's delight, enhancing the experiential customer value phenomena.'

Perhaps this story telling is one of the main reasons why the ratings on Airbnb seem to be much more positive than other rating systems such as for example TripAdvisor. Another reason for these positive responses maybe the result of the effect of 'socially induced reciprocity', which occur when sellers and buyers interact socially. This often results in reviewers omitting negative comments or information from reviews (Fradkin et al. 2014). Regardless of the reasons, the studies (Nosko - Tadelis 2015; Pallais 2014) show that positive ratings from the users increase a platform's chances of success.

\subsection{Competition: Difficulties Faced by Hotels}

The increasing popularity and growth of short-term letting platforms is ringing alarm bells at the major hotel chains' headquarters. These chains face a major threat to their bottom-line. Platforms such as Airbnb have a near zero-marginal cost structure, which translates into a huge advantage over the traditional hotel companies. Adding an extra 1000 rooms to Airbnb's portfolio will cost a fraction of what it will cost a hotel chain to add the similar 1000 rooms to its existing inventory. The removal costs are similarly very small for Airbnb. This near zeromarginal cost allows the Airbnb and other platforms to scale their supply at a very low cost to meet demand. Hotels face tremendous scaling problems. To scale-up they must either construct new hotels or buy existing ones. Constructing new hotels costs both money and time. Construction costs and furnishing are given. Finding the right place and complying with local zoning regulations is another problem that must be addressed. In addition, staffing is difficult and incurs additional costs. Moreover, safety regulations, obligatory reporting and other red tape is a larger challenge for hotels then for the entrants of the somewhat loosely regulated sharing economy. When a hotel chain decides on scaling-up, it must consider at a minimum a multi-year, if not a multi-decade return on investment period. Similarly, scaling down presents its own difficulties. Selling carries its own transaction costs, including costs of laying-off hotel staff.

Hotels are at a clear disadvantage and the industry is being disrupted. The question that remains is how the industry is affected and what should be done. Oskam and Boswijk (2016) present a dilemma for the authorities. They argue that banning the phenomenon will mean a disincentive for innovation, while policies that are more receptive may result in harmful commercialization in attractive destina- 
tions. In addition they may increase the number of illegal Airbnb units (Guttentag 2015), making the situation even worse for the hotels. Hotels are also concerned about the direction that Airbnb is taking. While previously Airbnb was not openly challenging hotels, it is assumedly beginning to capture an increasing share of the hotel market, by offering a hybrid hotel-Airbnb package. For example:

recently, Airbnb has been testing hotel-style packaging and amenities - such as local treats, wines, and upgraded bath products - in a select number of highly rated listings in Sonoma, California, to broaden its appeal to travelers who prefer more of a blend of a traditional hotel stay and that of an Airbnb: the comforts of a hotel stay like special amenities and treats as well as instant booking, combined with the more personalized, peer-to-peer, local experience that the Airbnb platform facilitates. Such efforts indicate Airbnb's intention to turn itself into a full-blown hospitality brand, one that delivers a seamless end-to-end experience when its customers travel. While the company initially disrupted the hospitality business by serving as a provider of alternative accommodation, it is now trying to take this disruption to the next level by competing along the lines of the guest experience. (Mody 2016: 4)

\subsection{The Effect on Hotels}

For most of the year, many hotels operate at break-even point and sometimes at a loss. During holidays and special events and occasions, the increase in demand presses the prices higher, leading to the major part of that year's profit. Airbnb increases the supply and thereby eats into that profit. For example, according to Zervas et al. (2015), Airbnb's expansion in Austin, Texas, has resulted in a 13\% reduction in hotel revenues. For Texas in general, they estimated a $0.35 \%$ decrease in monthly revenue for every $10 \%$ increase in Airbnb listings.

A recent report by HVS, a Hotel Valuations and Appraisals consultancy

estimated that hotels lose approximately $\$ 450$ million in direct revenues per year to Airbnb. Between September 2014 and August 2015, 480,000 hotel room nights were reserved while over 2.8 million room nights were booked on Airbnb. By 2018, HVS estimates that Airbnb room nights will reach 5 million per year. Clearly, the vacation rental site has diminished the demand for traditional hotel rooms. (Mahmood 2016)

Merril Lynch analysts also mention the impact. Huston (2015), citing these analysts, writes that by 2020 , Airbnb listings could make up $3.6 \%$ to $4.3 \%$ of the room inventory, forcing the hotels to lower their prices. This will of course affect the lower end hotels and motels most (Consigli et al. 2012; Jordan 2015), since these providers lack the business facilities of the larger hotels. 


\subsection{Situation in Norway}

There have been too few studies done on the effect of Airbnb on hotels in Norway, especially studies that have been peer reviewed. A Google Scholar search for the words 'Airbnb + Norge' produced only 105 hits, with only four relevant studies. Of these, there was one bachelor thesis (Duggmo et al. 2016) and three master theses (Furuholmen 2016; Jordet and Lehne 2016; Ytreberg 2016). A search for 'Airbnb+Norway+Hotel' gave 300 hits, and a search for 'Airbnb + Norway' gave 560 hits. Again, there were very few studies about the effect of Airbnb on hotels in Norway, and most were, as mentioned above, master theses. There was, however, one peer reviewed article by Neeser et al. (2015) in which he concludes that Airbnb had no significant effect on hotels' average revenue per available room in Norway, Sweden, and Finland.

The results from the master theses are rather different. All three theses (Furuholmen 2016; Jordet and Lehne 2016; Ytreberg 2016) report the negative effect of Airbnb on hotels in Norway. Jordet and Lehne (2016) report a 0.4\% decrees in hotels' revenue for every $10 \%$ increase in Airbnb's listings in the area, while Ytreberg (2016) reported a $0.3 \%$ decrease in hotel revenues. As is evident, there are few peer-reviewed articles published on this subject and of those, very few are focused on Norway. It is therefore the aim of this paper to contribute to the general knowledge in this area by investigating the effect of Airbnb on the Norwegian hotel industry.

There are two most direct ways in which the Airbnb may affect the hotel industry. First, the increasing number of available Airbnb listings may lead to potential hotel guests to switch to Airbnb. Customer loyalty to hotels and migration of clients to Airbnb has not been previously studied empirically. The following hypothesis is in line with what was suggested in other contexts (Mahmood 2016; Mody 2016):

H1. The growth in the occupancy rate of the hotels is negatively associated with Airbnb activity in the region.

Second, increasing supply of Airbnb listings may lead to imbalance between supply and demand on the accommodation market. Since the supply of hotel accommodations is not perfectly elastic, the new equilibrium state is only possible when the hotel prices decline in the short/medium run. In addition, since Airbnb prices are generally lower than hotels', it increases the pressure on the hotels to reduce their prices. Thus, we expect that price reduction and guest migration will result in lower income for the hotels.

H2. Hotel income is negatively associated with increasing Airbnb activity in the region. 


\section{METHODOLOGY}

The research design is divided into two categories, qualitative and quantitative. Rovai et al. (2013) citing Gall et al. (2007) categorize quantitative research design into two major types, namely experimental and non-experimental. Non-experimental design in turn is divided into three major types: descriptive/observational, causal comparative/ex-post-facto and correlational design. In this study, we rely on secondary data to examine the possible effects of Airbnb on the hotel industry in Norway. As such, we investigate possible relationships among various variables. This lends itself to the correlational design.

The correlational design, as the name implies, 'produces studies that examine relationships (i.e., correlation, association, co-variation) between two or more existing, non-manipulated variables drawing from a single group of research participants' (Rovai et al. 2013: 81).

In addition, we have used a causal comparative or 'ex post facto' approach as well. In this approach we attempt to determine the cause or consequences of differences that exist between or among groups of individuals, here we use the before and after division between the same group. To that end we used the difference-in-differences (DD) statistical method. Difference in differences (DD) is usually used to estimate treatment effects comparing the pre- and post-treatment differences in the outcome of a treatment and a control group. In this study the same group (before Airbnb) is used as the control group and the same group after Airbnb is considered as the treated group.

In addition, the results of the DD analyses are cross-checked when the relevant variables are entered stepwise into regression. When control variables are entered in the first step and then the variable measuring Airbnb activity is added, stepwise regression method allows to check if the last variable entered leads to any significant improvement of the regression model (i.e., a significant increase in adjusted $\mathrm{R}$ square is expected).

\section{DATA AND ANALYSIS}

\subsection{Data on Airbnb, Hotels and other Variables}

Data on Airbnb accommodations in Norway was supplied by AirDNA - an organization tracking the performance of Airbnb listings around the globe. The dataset includes information on number of reservations for each active Airbnb listing in Norway between 2014 and 2017. The original dataset included 26,031 active listings. It was possible to identify the exact location for 25,493 listings. These list- 
ings were attributed to 89 regions in Norway that correspond to the regions used by Norwegian Central Statistics Bureau for accommodation statistics.

Hotel statistics for period 2014-2016 were acquired from the Norwegian Central Statistics Bureau. Due to anonymity restrictions, the Bureau supplies data where the smallest administrative units with less than 3 hotels available are merged into larger regions. The following data on hotels at the regional level were available: hotel income from accommodations, hotel income per available room, number of rooms sold, number of room nights sold, time spent at average room, time spent at hotels (Norwegians), time spent at hotels (foreigners), income per room night sold, and income per room sold.

Regional data on population size and unemployment on 31 December 2016 comes from Norwegian Central Statistics Bureau.

\subsection{Analysis}

Comparing Airbnb development to hotel market development on the regional level presented several challenges. First, the absolute number of Airbnb reservations is closely associated with the region's location and population size. In the context of this study, the population size strongly influences the number of hotel accommodations as well, making it difficult to use absolute numbers to detect the effect of Airbnb on the hotel industry. Second, while it is easy to calculate the growth rate for the hotels in most of the regions, the growth pattern of Airbnb is more complicated. Only 10 of 89 regions in Norway had any Airbnb reservations in 2013. The respective numbers were 13 in 2015 and 85 in 2016. This means most regions had undefined growth in 2016 compared to 2014 and 2015. Third, the vast differences in growth rates for the hotel industry in different regions suggests that local factors play an important role, leading to the conclusion that the local trends should be accounted for.

In this paper, the observed number of Airbnb reservation days in 2016 was compared to the differences between the observed and the expected growth in hotel guest nights in 2016. To estimate the expected growth in hotel guest nights in 2016, the average growth in hotel guest nights in each region in period 20092013 was calculated. This period was chosen as preceding the appearance of Airbnb listings in most of the Norwegian regions. Considering the exponential growth rate for Airbnb services, the absolute number of Airbnb guests was insignificantly small before 2013 . The average annual growth in hotel guest nights varied between -17 to $+50 \%$ (mean: $0.5 \%$, standard deviation: $8.8 \%$ ). Then, the expected number of hotel guest nights in 2016 was estimated as the result of multiplication of the regional number of hotel guest nights in 2013 by the cube 
of the average growth rate for the region. Finally, the expected number of hotel guest nights in 2016 was subtracted from the observed number and divided by the number hotel guest nights in 2013:

$$
\Delta N_{2016}=\frac{N_{2016}-N_{2013} * \overline{G_{2009-13}}}{N_{2013}}
$$

Where $\Delta \mathrm{N}_{2016}$ is the relative deviation of the observed hotel guest nights in 2016 from the expected based on the 2009-2013 trend; $\mathrm{N}_{\mathrm{x}}$ is the observed number of hotel guest nights in year $\mathrm{x} ;{\overline{G_{2009-13}}}^{3}$ is the average growth in the observed hotel guest nights in the period between 2009 and 2013.

Another dependent variable used is hotel income per occupied room in 2016. It varied from NOK 510 to NOK 996 across the regions. Concentration of Airbnb services was calculated as number of reservation days per capita. Airbnb's market share in each region was calculated as a number of Airbnb reservations divided by the hotel guest nights.

\section{RESULTS}

\subsection{Correlational Analysis}

The total number of guest nights spent in Norway in 2016 was $16,52,400$ ranging from over 465,000 in Oslo to less 36,000 in some smaller regions. The same year Airbnb listings were reserved for 694,224 nights. Over half of these nights (52\%) were spent in Oslo. Average number of Airbnb reservations per hotel guest night was 0.017 . Since we do not know the number of Airbnb guests, this number is a minimum estimation for Airbnb's market share (1.7\%). This number varied from $0.1 \%$ in some regions to over $7 \%$ (in two of the largest cities in Norway (Oslo and Bergen).

The number of guest nights was strongly positively correlated with both the number of Airbnb reservations and concentration of Airbnb reservations per person living in a particular region. However, this association is mostly explained by the fact that both the number of hotel accommodations and Airbnb listings is dependent on the region's population. When the measure independent from region population was applied, no significant correlation was found between Airbnb reservations (measured in absolute numbers and related to regional population and hotel guest nights) and the relative growth in hotel guest nights (as compared to the numbers predicted by the previous trends). Thus, hypothesis $\mathrm{H} 1$ is not supported. 
No significant correlation was observed between hotel income per occupied room and any of the variables in this analysis (Table 2). Further, difference-indifferences analysis was applied.

Table 2. Descriptive statistics and Pearson correlations $(\mathrm{N}=86)$.

\begin{tabular}{l|c|c|c|c|c|c|c|c}
\hline & Mean & SD & 1 & 2 & 3 & 4 & 5 & 6 \\
\hline $\begin{array}{l}\text { 1. Hotel guest } \\
\text { nights }\end{array}$ & 270908 & 644995 & 1 & & & & & \\
\hline $\begin{array}{l}\text { 2. Airbnb reserva- } \\
\text { tions }\end{array}$ & 8072 & 41530 & $0.966^{* *}$ & 1 & & & & \\
\hline $\begin{array}{l}\text { 3. Region's popu- } \\
\text { lation }\end{array}$ & 33848 & 80560 & $0.959^{* *}$ & $0.955^{* *}$ & 1 & & & \\
\hline $\begin{array}{l}\text { 4. Airbnb reserva- } \\
\text { tion per hotel guest } \\
\text { night }\end{array}$ & 0.017 & 0.017 & $0.597^{* *}$ & $0.649^{* *}$ & $0.676^{* *}$ & 1 & & \\
\hline $\begin{array}{l}\text { 5. Airbnb reserva- } \\
\text { tions per capita }\end{array}$ & 0.110 & 0.113 & $0.587^{* *}$ & $0.566^{* *}$ & $0.481^{* *}$ & $0.605^{* *}$ & 1 & \\
\hline $\begin{array}{l}\text { 6. Hotel guest } \\
\text { night deviation } \\
\text { from trend }\end{array}$ & 0.056 & 0.414 & 0.018 & 0.028 & -0.012 & 0.024 & 0.147 & 1 \\
\hline $\begin{array}{l}\text { 7. Hotel income } \\
\text { per occupied room }\end{array}$ & 835.11 & 99.626 & 0.273 & 0.232 & 0.257 & 0.208 & 0.271 & -0.049 \\
\hline
\end{tabular}

* $\rho \leq 0.05$ (2-tailed); $* * \leq 0.01$ (2-tailed)

\subsection{Difference-in-Differences (DD) analysis}

The following regression model was applied to different dependent variables:

$$
H_{r c t}=\beta_{0}+\beta_{1} \text { Airbnb }_{r t}+\beta_{2} \text { Controls }_{r t}+\beta_{3} \text { HSupply }_{c}+\beta_{4} \text { ERate }_{t}+\beta_{5} X_{c t}+\varepsilon_{r c t}
$$

Where:

$H_{r t c}$ is one of the dependent variables describing hotels' income, occupancy and price-level each year in every region. Specifically, the following dependent variables were tested:

Hotel income:

- Hotel income from accommodations

- Hotel income per available room

Visits:

- Number of rooms sold

- Number of room nights sold

- Time spent at average room 
- Time spent at hotels (Norwegians)

- Time spent at hotels (Foreigners)

Price indicators:

- Income per room night sold

- Income per room sold

Airbnb $b_{r t}$ is a number of Airbnb reservations at any given year at each region. We have also tested a dichotomic variable (1 if Airbnb is present in the region and 0 otherwise), but this less precise measurement resulted in no significant regression coefficients.

Controls $_{r t}$ are control variables (population and unemployment rate in each region for each year). Population is used as a proxy for demographic change and unemployment is used as a proxy for economic activity in a region.

HSupply is the total number of hotels in each county-region (19 Norwegian counties were aggregated into 5 county-regions). This county-fixed variable takes into account the total supply of hotel rooms in a county-region controlling for the effects of new hotels built and old hotels taken out of service. Such changes influence all the hotels in a certain area.

$\beta_{4}$ ERate is an exchange rate of Norwegian krone to EUR. The reason we include this time-fixed variable is that the total attractiveness of Norway for foreign tourists is influenced by the exchange rate. Both USD and EUR were checked, and the effects were strongest for EUR. Since Norway attracts many more tourists from European countries then from USA, the EUR/NOK exchange rate was used in the analysis.

$X_{c t}$ is a term accounting for interaction between county-fixed and time-fixed effects.

The results of regression analysis are summarized in Table 3.

Among the control variables, population is positively related to hotel income from accommodation, hotel income per available room, number of rooms sold, number of room nights sold and income per room/night sold. Thus, hotels in larger (in terms of population) regions sell more rooms at higher prices.

Unemployment is negatively related to hotel income and the number of rooms and room nights sold, suggesting that a higher unemployment rate (as a proxy for business activity in the region) leads to weaker demand for hotels. Business activity does not look to have any immediate effect on hotel prices.

The results of the regression analysis indicate that hotel income from accommodation is positively related to Airbnb activity in the region. Stepwise regression additionally confirmed that adding Airbnb activity to the control variables leads to increased adjusted R square, indicating that Airbnb has an independent significant effect on hotel income. Thus, hypothesis 1 is not supported. 
Table 3. Results of the difference-in-differences analysis $(\mathrm{N}=86)$.

\begin{tabular}{|c|c|c|c|c|c|c|c|}
\hline \multirow[t]{2}{*}{ Dependent variable } & \multicolumn{6}{|c|}{ Std. $\beta$} & \multirow{2}{*}{$\begin{array}{l}\text { Adjusted } \\
\text { R Square }\end{array}$} \\
\hline & Airbnb & Population & $\begin{array}{l}\text { Unemploy- } \\
\text { ment }\end{array}$ & $\begin{array}{c}\text { County } \\
\text { Hotel } \\
\text { Supply }\end{array}$ & $\begin{array}{c}\text { Exchange } \\
\text { rate }\end{array}$ & $\mathrm{X}_{\mathrm{ct}}$ & \\
\hline \multicolumn{8}{|l|}{ Total hotel income: } \\
\hline $\begin{array}{l}\text { Hotel income from ac- } \\
\text { commodations }\end{array}$ & $0.121 * * *$ & $0.888 * * *$ & $-0.089 * * *$ & 0.048 & -0.008 & -0.043 & 0.923 \\
\hline $\begin{array}{l}\text { Hotel income per avail- } \\
\text { able room }\end{array}$ & -0.145 & $0.493 * * *$ & -0.015 & -1.17 & -0.105 & 1.104 & 0.143 \\
\hline \multicolumn{8}{|l|}{ Visits: } \\
\hline Number of rooms sold & $0.111^{* * *}$ & $0.894 * * *$ & $-0.087 * * *$ & 0.075 & 0.002 & -0.072 & 0.918 \\
\hline $\begin{array}{l}\text { Number of room nights } \\
\text { sold }\end{array}$ & $0.133^{* * *}$ & $0.875^{* * *}$ & $-0.098^{* * *}$ & 0.096 & 0.007 & -0.088 & 0.913 \\
\hline $\begin{array}{l}\text { Time spent at average } \\
\text { room }\end{array}$ & -0.059 & 0.155 & -0.023 & -0.036 & -0.027 & 0.020 & -.009 \\
\hline $\begin{array}{l}\text { Time spent at hotels } \\
\text { (Norwegians) }\end{array}$ & -0.076 & $0.180^{*}$ & -0.073 & 0.031 & 0.001 & -0.070 & -.004 \\
\hline $\begin{array}{l}\text { Time spent at hotels } \\
\text { (Foreigners) }\end{array}$ & -0.017 & 0.050 & 0.041 & -0.328 & -0.082 & 0.257 & -.011 \\
\hline \multicolumn{8}{|l|}{ Prices: } \\
\hline $\begin{array}{l}\text { Income per room night } \\
\text { sold }\end{array}$ & -0.143 & $0.301 * *$ & $0.152 *$ & -1.553 & -0.233 & 1.381 & .118 \\
\hline Income per room sold & -0.084 & $0.222 *$ & 0.063 & -1.203 & -0.172 & 1.100 & .035 \\
\hline
\end{tabular}

*** significant at .0001 level. ** significant at .001 level. * significant at .05 level.

To decompose this effect, we look further at the effects of Airbnb on the number of hotel guests and the price level. In the regions with a larger number of Airbnb guests, hotels sell more accommodations to a larger number of guests than in the regions where Airbnb is less popular. Stepwise regression additionally confirmed that Airbnb has an independent positive effect on number of rooms and room nights sold. This result contradicts to H2. Income per room and room night sold are independent of Airbnb activity. It may indicate that hotels are not pressed to reduce prices in the regions with high Airbnb activity.

\section{CONCLUSION AND FUTURE WORK}

The results of the analys indicate that at the regional level, the growth rate of hotel guest nights is independent from the development of Airbnb listings. On average, the hotels in the regions where Airbnb is flourishing do not demonstrate lower growth rates compared to the regions where Airbnb is absent, or the number of Airbnb guests is relatively small. Moreover, we did not detect any negative relationship between Airbnb activities in the regions and hotel prices. To the contrary, the regression analysis confirmed that Airbnb has an independent 
positive effect on the number of rooms and room nights sold. It is plausible that Airbnb guests that would not otherwise visit the region may spend some nights at hotels, leading to increased demand also in this sector. It is also possible, that larger penetration of Airbnb helps to spread information about the destination and signals to potential tourist that a particular region is a well-developed tourism destination. At this time at least, the increasing presence of Airbnb may increase the visibility of the region for tourism and contribute to the increasing tourist traffic into the region, hence positively contributing to the number of rooms and room nights sold. We can also think about the possibility of reverse causality, saying in effect that since the region is already an attractive tourist destination, it attracts increasing Airbnb listings.

However, overall, these findings suggest that Airbnb customers are different from the traditional hotel guest, i.e., they possibly would not have visited the place had the prices not been suitable. For example, the cost of a European vacation for an extended family of over 5 people can be prohibitive when one thinks of the hotel costs and food. A villa with 4 to 5 bedrooms through Airbnb would reduce the costs by half, making it possible for this family to take that vacation. In other words, the availability of Airbnb can bring in tourists that otherwise would not have visited the place. It is also possible that Airbnb guests value additional social benefits in the form of communicating with hosts and untraditional accommodations not available through the ordinary hotel market (boats, cabins, mobile homes, etc.).

As can be seen, at some level, Airbnb and hotels do not (currently) compete for the same customers. However, this ambiguity about the effect of Airbnb may be short-lived, as Airbnb starts to expand further in other areas, such as business travel.

'Airbnb for business', as it is called, focuses exclusively on business travel managers and the general business travelers. Its 'one-click expensing', that can charge directly to the companies, along with 24-hour premium support tries to emulate the services offered by normal hotels. This service can become a serious threat to the existing hotel chains (Zaleski 2017). In the long run, an increase in the total number of available hotel rooms, regardless of segment, may increase supply and alter the supply/demand/price curves. Even if it is not observable in the short run, the market is elastic for both supply and demand. This will, as sharing platforms continue developing, at the very least put a ceiling on hotels' prices and hence their profits, and in the worst case lead to their bankruptcy. The hotels specializing in luxury rooms and suites are not immune either, as Airbnb is said to be planning a new tier of luxury vacation rentals (Gurman - Zaleski 2017). However, these effects will vary dramatically between different countries and regions. 
The results of this study contradict some previous studies' findings of Airbnb having a negative effect on hotel industry. One possible explanation can be that most of the studies have focused on large cities and metropolitan areas, while our study looks at a mixture of both small and large regions. While it is argued in this study that Airbnb has generally positive effect for hotels, it is possible that one may find negative effects in some more developed and larger regions.

The study has several implications for practitioners. First, the proponents of the restrictive regulations of Airbnb and other short-term letting platforms should not overemphasize the negative consequences on the hotel industry. Since the share of Airbnb listings on the accommodation market varies dramatically between regions, it is likely that eventual regulations/restrictions should be introduced on the regional, local and even neighborhood levels, while most of the regions continue benefiting from the increasing number of Airbnb visitors.

Although this study showed that currently the hotel industry in Norway is safe from Airbnb, it does not mean that it is safe from competition. The hotel industry is facing tremendous challenges from Airbnb in the very near future. The next step in future research is to map the responses of hotels to these challenges.

We must also mention the limitations of the quantitative method employed in this paper. Many aspects of competition in the hotel industry deal with subjects such as customer satisfaction, service quality perception, security perception, etc., that demands a more subjective analysis, more suitable for a qualitative approach. Having said that, we feel confident that for our purpose, quantitative methods, although not completely optimal, have been appropriate.

Additional research on consumer preferences and behavior are needed to understand the extent to which the platforms are taking clients from the hotels, and what clients value most. It may also be interesting to investigate if the clients that use Airbnb in one location use hotels in another location on their journey. This kind of additional research may help the accommodation industry in general and hotels in particular not only to survive in competition with peer-to-peer letting platforms, but also to benefit from the growth of the novel technologies and business models.

\section{REFERENCES}

Agyeman, J. - McLaren, D. - Schaefer-Borrego, A. (2013): Sharing Cities. Friends of the Earth Briefing, https://friendsoftheearth.uk/sites/default/files/downloads/agyeman_sharing_cities.pdf, accessed 20/09/2018.

Brown, B. - Chalmers, M. (2003): Tourism and Mobile Technology. In The European Conference on Computer-Supported Cooperative Work. Springer, Dordrecht pp. 335-354. 
Brown, H. S. - Vergragt, P. J. (2015): From Consumerism to Wellbeing: Toward a Cultural Transition? Journal of Cleaner Production 132: 308-317.

Camisón, C. - Monfort-Mir, V. M. (2012): Measuring Innovation in Tourism from the Schumpeterian and the Dynamic-Capabilities Perspectives. Tourism Management 33(4): 776-789.

Choudary, S. P. (2015): Platform Scale: How an Emerging Business Model Helps Startups Build Large Empires with Minimum Investment. Platform Thinking Labs.

Chu, R. K. S. - Choi, T. (2000): An Importance-Performance Analysis of Hotel Selection Factors in the Hong Kong Hotel Industry: A Comparison of Business and Leisure Travelers. Tourism Management 21(4): 363-377.

Consigli, M. - Gallagher, M. - Kumar, M. - Mehta, N. - Purnell, J. - Templeton, R. (2012): EIS Final Project: Airbnb. Hanover: Dartmouth College.

Dickinson, J. E. - Hibbert, J. F. - Filimonau, V. - Cherrett, T. - Davies, N. - Norgate, S. - Winstanley, C. (2017): Implementing Smartphone Enabled Collaborative Travel: Routes to Success in the Tourism Domain. Journal of Transport Geography 59: 100-110.

Duggmo, O. C. - Smedsland, L. G. - Andersson, N. (2016): "Be a Traveler, not a Tourist" - AirBnb's påvirkning på hotellnæringen. BSc. thesis. https://brage.bibsys.no/xmlui/handle/11250/2420227, accessed 20/09/2018.

Fradkin, A. - Grewal, E. - Holtz, D. - Pearson, M. (2014): Bias and Reciprocity in Online Reviews: Evidence From Field Experiments on Airbnb. https://pdfs.semanticscholar.org/ecd4/37ee283eef 574472b1e621cefb0e52544edf.pdf, accessed 20/09/2018.

Furuholmen, J. M. (2016): Delingsøkonomiens fremvekst: Effekten av Airbnb på hotellbransjen i Norge. https://www.duo.uio.no/handle/10852/53913, accessed 20/09/2018.

Gall, M. D. - Gall, J. - Borg, W. (2007): Educational Research: An Introduction. Pearson.

Gunawan, K. - Purnama, B. E. (2015): Implementation of Location Base Service on Tourism Places in West Nusa Tenggara by Using Smartphone. International Journal of Advanced Computer Science and Applications 6(8).

Gurman, M. - Zaleski, O. (2017): Airbnb Said to Be Planning New Tier for Luxury Vacation Rentals. Bloomberg. https://www.bloomberg.com/news/articles/2017-06-29/airbnb-said-to-beplanning-new-tier-for-luxury-vacation-rentals, accessed 20/09/2018.

Guttentag, D. (2015): Airbnb: Disruptive Innovation and the Rise of an Informal Tourism Accommodation Sector. Current Issues in Tourism 18(12): 1192-1217.

Heinrichs, H. (2013): Sharing Economy: A Potential New Pathway to Sustainability. Gaia 22(4): 228-231.

Hjalager, A. M. (2015): 100 Innovations that Transformed Tourism. Journal of Travel Research 54(1): 3-21.

Huston, C. (2015): As Airbnb Grows, Hotel Prices Expected to Drop. http://www.marketwatch. com/story/as-airbnb-grows-hotel-prices-expected-to-drop-2015-08-13, accessed 21/04/2017.

Jordan, G. (2015): Airbnb not Just a Worry, but 'Tectonic Shift.' Hotel News Now 26.

Jordet, A. - Lehne, T. (2016): Utfordringer med delingsøkonomien: er Airbnb en konkurrent til hotellnæringen? https://brage.bibsys.no/xmlui/handle/11250/2403973, accessed 20/09/2018.

Kandampully, J. - Suhartanto, D. (2000): Customer Loyalty in the Hotel Industry: The Role of Customer Satisfaction and Image. International Journal of Contemporary Hospitality Management 12(6): 346-351.

Kassan, J. - Orsi, J. (2012): Legal Landscape of the Sharing Economy. The Journal of Environmental Law and Litigation 27(1).

Korpilo, S. - Virtanen, T. - Lehvävirta, S. (2017): Smartphone GPS Tracking - Inexpensive and Efficient Data Collection on Recreational Movement. Landscape and Urban Planning 157: 608-617. 
Lewis, R. C. (1985): Getting the Most from Marketing Research: [Part V] Predicting Hotel Choice: The Factors Underlying Perception. Cornell Hotel and Restaurant Administration Quarterly 26(3): 82-96.

Lewis, R. C. - Chambers, R. E. (1989): Marketing Leadership in Hospitality. Foundations and Practices. Van Nostrand Reinhold.

Mahmood, A. (2016): The Impact of AirBnb on Hotel and Hospitality Industry. Hospitality Net. http://www.hospitalitynet.org/news/4074708.html, accessed 21/04/2017.

Martin, C. J. - Upha m, P. - Budd, L. (2015): Commercial Orientation in Grassroots Social Innovation: Insights from the Sharing Economy. Ecological Economics 118: 240-251.

Mathis, E. F. - Kim, H. L. - Uysal, M. - Sirgy, J. M. - Prebensen, N. K. (2016): The Effect of coCreation Experience on Outcome Variable. Annals of Tourism Research 57: 62-75.

McCleary, K. W. - Weaver, P. A. - Hutchinson, J. C. (1993): Hotel Selection Factors as They Relate to Business Travel Situations. Journal of Travel Research 32(2): 42-48.

Miles, I. (2008): Patterns of Innovation in Service Industries. IBM Systems Journal 47(1): 115128.

Mody, M. (2016): Creating Memorable Experiences: How Hotels can Fight back against Airbnb and Other Sharing Economy Providers. Boston Hospitality Review 4(2): 1-9.

Mohler, J. (2015): Just Do It: The Manufacturing of the Neoliberal Subject. Gnovis Journal 16(1).

Morozov, E. (2013): The 'Sharing Economy' Undermines Workers' Rights - My FT Oped. https:// evgenymorozov.tumblr.com/post/64038831400/the-sharing-economy-undermines-workersrights, accessed 16/04/2017.

Neeser, D. - Peitz, M. - Stuhler, J. (2015): Does Airbnb Hurt Hotel Business: Evidence from the Nordic Countries. Master Thesis, Universidad Carlos III de Madrid.

Nosko, C. - Tadelis, S. (2015): The Limits of Reputation in Platform Markets: An Empirical Analysis and Field Experiment. National Bureau of Economic Research WP 20830.

Oskam, J. - Boswijk, A. (2016): Airbnb: The Future of Networked Hospitality Businesses. Journal of Tourism Futures 2(1): 22-42.

Pallais, A. (2014): Inefficient Hiring in Entry-Level Labor Markets. The American Economic Review 104(11): 3565-3599.

Parasuraman, A. - Zeithakm, V. A. - Berry, L. L. (1988): SERVQUAL: A Multiple-Item Scale for Measuring Consumer Perceptions of Service Quality. Journal of Retailing 64(1): 12.

Pera, R. (2017): Empowering the New Traveler: Storytelling as a co-Creative Behavior in Tourism. Current Issues in Tourism 20(4): 331-338.

Rovai, A. P. - Baker, J. D. - Ponton, M. K. (2013): Social Science Research Design and Statistics: A Practitioner's Guide to Research Methods and IBM SPSS. Watertree Press LLC.

Schumpeter, J. A. (1942): Capitalism, Socialism, and Democracy (Second Edition Text). Impact Books.

Shaw, G. - Bailey, A. - Williams, A. (2011): Aspects of Service-Dominant Logic and Its Implications for Tourism Management: Examples from the Hotel Industry. Tourism Management 32(2): 207-214.

Slee, T. (2016): What's Yours Is Mine: Against the Sharing Economy. OR Books.

Vargo, S. L. - Lusch, R. F. (2004): Evolving to a New Dominant Logic for Marketing. Journal of Marketing 68(1): 1-17.

WTTC. (2017): Travel and Tourism: Global Economic Impact and Issues 2017. https://www.wttc. org:443/research/economic-research/economic-impact-analysis/, accessed 17/04/2017.

Ytreberg, N. S. (2016): Competitive Effects of Airbnb on the Norwegian Hotel Market. Master's Thesis, University of Bergen. http://beccle.no/files/2016/12/Masteroppgave_NSY2.pdf, accessed 17/04/2017. 
Zaleski, O. (2017): Airbnb Readies a Premium Tier to Compete More with Hotels, Sources Say. Bloomberg. https://www.bloomberg.com/news/articles/2017-06-21/airbnb-said-to-ready-apremium-tier-to-compete-more-with-hotels, accessed 08/08/2017.

Zervas, G. - Proserpio, D. - Byers, J. (2015): A First Look at Online Reputation on Airbnb, Where Every Stay Is above Average. http://papers.ssrn.com/sol3/papers.cfm?abstract_id=2554500, accessed 20/09/2018.

Zheng, W. - Huang, X. - Li, Y. (2017): Understanding the Tourist Mobility Using GPS: Where is the Next Place? Tourism Management 59: 267-280.

Open Access. This is an open-access article distributed under the terms of the Creative Commons Attribution-NonCommercial 4.0 International License (https:// creativecommons.org/licenses/by-nc/4.0/), which permits unrestricted use, distribution, and reproduction in any medium for non-commercial purposes, provided the original author and source are credited, a link to the CC License is provided, and changes - if any - are indicated. 